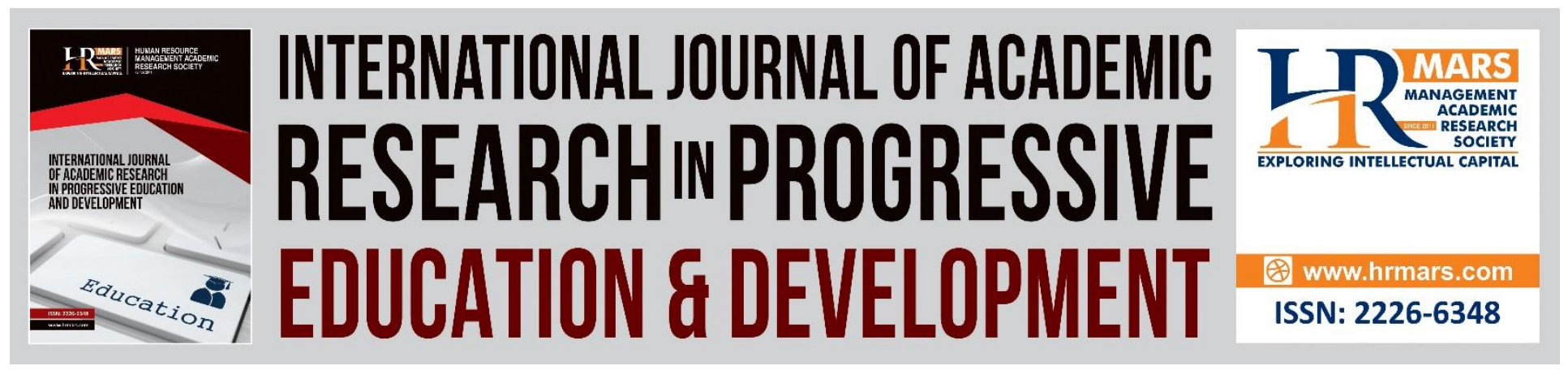

\title{
The Feedback of Using Edmodo Application in Teaching and Learning of Moral Education in Secondary School
}

Hairul Faiezi Lokman, Nik Mohd Rahimi Nik Yusoff, Fariza Khalid, Nurfaradilla Mohamad Nasri

To Link this Article: http://dx.doi.org/10.6007/IJARPED/v7-i4/4851

DOI: $10.6007 /$ IJARPED/v7-i4/4851

Received: 08 Sept 2018, Revised: 19 October 2018, Accepted: 07 Nov 2018

Published Online: 17 Nov 2018

In-Text Citation: (Lokman, Yusoff, Khalid, \& Nasri, 2018)

To Cite this Article: Lokman, H. F., Yusoff, N. M. R. N., Khalid, F., \& Nasri, N. M. (2018). The Feedback of Using Edmodo Application in Teaching and Learning of Moral Education in Secondary School. International Journal of Academic Research in Progressive Education and Development, 7(4), 246-254.

Copyright: (C) 2018 The Author(s)

Published by Human Resource Management Academic Research Society (www.hrmars.com)

This article is published under the Creative Commons Attribution (CC BY 4.0) license. Anyone may reproduce, distribute, translate and create derivative works of this article (for both commercial and non-commercial purposes), subject to full attribution to the original publication and authors. The full terms of this license may be seen

at: http://creativecommons.org/licences/by/4.0/legalcode

\section{Vol. 7, No. 4, 2018, Pg. 246 - 254}




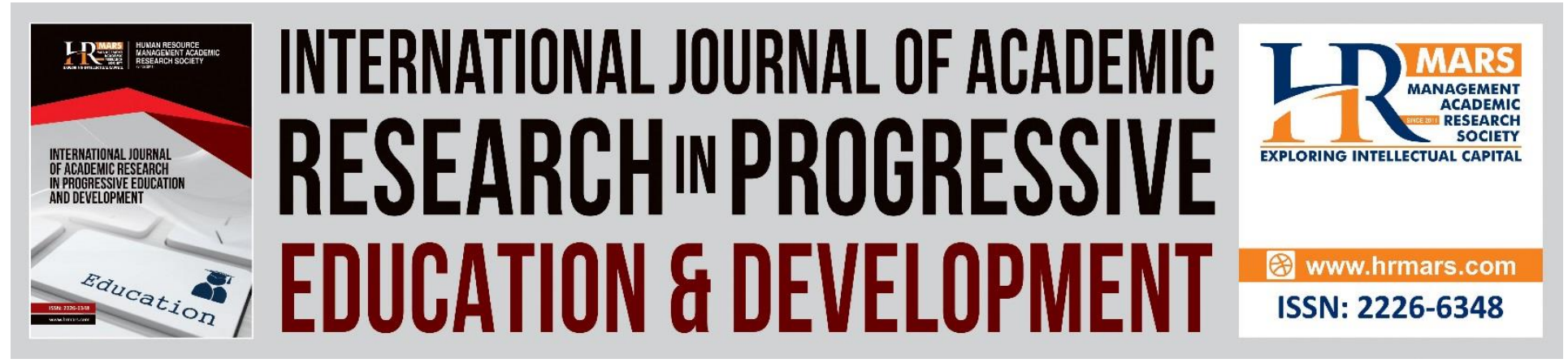

\title{
The Feedback of Using Edmodo Application in Teaching and Learning of Moral Education in Secondary School
}

\author{
Hairul Faiezi Lokman \\ Faculty of Education, National University of Malaysia, Malaysia. \\ Email: faieziy@gmail.com \\ Nik Mohd Rahimi Nik Yusoff \\ Faculty of Education, National University of Malaysia, Malaysia. \\ Fariza Khalid \\ Faculty of Education, National University of Malaysia, Malaysia. \\ Nurfaradilla Mohamad Nasri \\ Faculty of Education, National University of Malaysia, Malaysia.
}

\begin{abstract}
Edmodo is a social media concept of virtual education which helps teachers, students and parents in a form of new style of learning. Current developments have witnessed a change in the way of students learning in line with technological developments. This study was conducted using an action research model adapted from Kemmis and Mc Taggart (1988), which aims to identify students' feedback on the use of this application in PDP Moral Education. This qualitative research involving 23 pupils Moral Education Form 4, from 3 classes of all races comprising china, india and etc. Data were analyzed using analysis of documents and interviews focus groups through theme analysis method. The findings showed that Edmodo application has given a very good feedback from the students during the teaching session. Edmodo app has encouraged students to learn as they are interested in learning using this method, style and use of multimedia technology-based education. The feedback also showed that application of Edmodo has been able to improve their knowledge through induction set, read the notes using the web, Blind Spaces application and through interactive activities generated. These findings has provide new ideas in the process of teaching moral education in school pedagogy and also support the transformation of education in line with Malaysian Education Blueprint (PPPM 2013-2025) which is to make technology as a medium of teaching styles.
\end{abstract}


INTERNATIONAL JOURNAL OF ACADEMIC RESEARCH IN PROGRESSIVE EDUCATION AND DEVELOPMENT

Vol. 7, No. 4, 2018, E-ISSN: 2226-6348 ๑ 2018 HRMARS

Keywords: Edmodo, Moral Education, Feedback

\section{Introduction}

The subject of moral education have been taught in the schools of malaysia since 1984 (visalache, 2012). This subject is taken by non-muslim students, i.e. Chinese and indian students. Teaching time for this subject is parallel to the subject of islamic education. The core principles in teaching and learning of moral education are physical, emotional, intellectual, spiritual, and social aspects as stated in the syllabus (ministry of education malaysia (moe) of the moral education syllabus for secondary schools 2000;1). From time to time, the teaching and learning for moral education subject is enhanced in line with current developments, particularly on the explosion of human traits and behaviors in today's globalization era (hairul faiezi, 2016).

The teaching and learning of moral education subject need to grow especially in the delivery of teaching and aspects of pedagogical teaching. Presentation and teaching tools should be in line with the challenging and demanding era. According to howell and howell (2003), the development of digital application-based teaching methods has a beneficial impact on students. Digital learning has a variety of patterns and methods that give various benefits to students. Learning using computer-based technology (computer-supported collaborative learning (cscl)) provides a diverse range of learning styles as well as giving a good impression of a teaching process delivered by the teachers (kreijns et al., 2003). This style of learning will also expand the collaborative learning form of students through various online activities (stahl, 2006).

This study is carried out to diversify the teaching and learning method of moral education subject by making the edmodo application as a new style of teaching in the classroom. The edmodo application was used as a learning management system (Ims) to students. Students and teachers interact, exchange notes, send messages, answer questions as if the normal learning in the classroom, but this time it was manifested in an internet-based technology medium. The purpose of this study is to explore students' feedback on the use of edmodo application in the teaching and learning of moral education subject in secondary schools.

\section{Literature Reviews}

Several previous studies on the use of edmodo application in the teaching process demonstrated some positive findings on the effects in the teaching and learning process. The study of grosseck and holotescu (2010) on the students showed that edmodo microblogging web 2.0 has improved the quality of learning because it was a student-oriented application. Meanwhile, balasubramaniam (2014) has conducted a questionnaire on 249 students on learning using the edmodo application. His findings showed that the edmodo application has embarked on student engagement and formed a comprehensive learning pattern, for example a student must be responsible when an assignment was given through exercises uploaded in the edmodo.

The findings by kandappan are similar to the study conducted by kongchan (2014) toward 17 english teachers at a school. His findings postulated that the edmodo application is a comprehensive and engaging learning channel as well as suitable for teaching in the classroom. Despite attracting interest, the edmodo application also expands students' mastery over a 
Vol. 7, No. 4, 2018, E-ISSN: 2226-6348 @ 2018 HRMARS

learning topic. For example, a study by monalisa and ardi (2013) showed the improvement of english language among students when using this application in the teaching process. Students can develop grammar and sentence writing in english by enriching vocabulary knowledge.

Another study by yagci (2015) showed that technology can change a perception. About 171 students were participated in the study conducted at a university in iraq. Iraq is a country that does not apply information technology in education. However, when technology-assisted learning using the edmodo application of Ims was introduced, the students' feedback and motivation improved. Various benefits such as new collaborative styles, enhancing modern classroom experience and sharing resources of a wide range of information also exist through the research done by thogmak (2013) in the teaching and learning process. Some of these studies have shown that edmodo application has had positive effects in the teaching and learning process.

\section{METHODOLOGY}

This study was an action study using the action model of kemmis and mc taggart (1988). The sampling in this study consisted of 23 students of form 4 in a secondary school who took moral education subject among chinese, indian and other races. A group of five students was selected for the study conducted. The study used two circles of action study for three months through planning, action, observation and reflection in every series of study circles. The interviewing instrument, and analysis of the document were used as an instrument for collecting data in two circles of action study. The data obtained were then transcribed, filtered, coded, and subsequently the production of the theme was done.

\section{Research Findings}

Based on the analysis done, two themes showed the effectiveness of edmodo application on the teaching and learning of moral education subject in secondary school, which were to encourage learning and enriching knowledge.

\section{ENCOURAGE LEARNING INTEREST}

The findings from this study showed that students' interest in learning has been driven by the use of edmodo application. There were four sub themes that justified the edmodo application has encouraged students' interest based on several indicators, namely easy to implement activities, group learning, interactive training and teaching aids (bbm).

The activities that can be found in the edmodo application could easily be done by the students. Students will not feel overwhelmed and depressed by the lessons they are learning as the edmodo application diversifies the style and learning patterns different from the traditional learning. Respondents 1 , for example, stated that this app did not put pressure on his control.

"... Through the learning process of edmodo, it felt that the learning processes became less stressful and easier to do all the work given by the teacher..." (g1r1m1b13) 
In addition, this application is easy to be used by anyone as well as easily carried out by the students. Students also enjoy the learning experiences delivered by the teachers. Respondent 4 stated that this application was more fun than the current learning in school.

"...i felt more fun compared to what we have at shool currently.." (g1r4m1b13)

The features of the edmodo application that can shape learning within the group through discussion in the edmodo forum and good collaboration shown by fellow group members also encourage students' interest in learning. For example, through the interview conducted to the second respondent of this study:

"..i generally understand that it is possible to work together in groups to solve problems such as working together to find accurate and correct answers for the questions given by the teachers, and another thing we can self-learning more effectively.." (g2r3m1b10)

Interactive training in this application also attracts students' interest in learning. Using the edmodo application, exercises are given interactively and virtually for the students to answer the questions given in the application. Students only need to give their answers in the edmodo application without having to write on any exercise book or note. This makes it easy to answer the questions. Respondent 4 in the first circle, for example, said that the edmodo application made it easy for him to answer the question using his own ideas and he was also happy with the method of questioning used. Here are the quotes of the interview:

"...so happy and easy to answer and issue my own ideas.." (g1r3m1b13)

An analysis of the document showed that all students have completed and answered all the kbat questions given within the stipulated time. This demonstrated a good encouragement on using this application to students through positive feedbacks in the kbat exercises provided (ad/g1/ kbatexercises).

The teaching tools using youtube in this study have also encouraged students' interest in learning using this application. A student in the second circle of interview stated the advantages of the induction set provided by the researcher through the youtube page. Respondents 1 and respondents 2, for example, stated that the advantage of using video through this youtube page was to facilitate them to receive and absorb the values studied as interpreted in the interview below:

"...the usage of this video can be adopted easily because student will understand more on the content..." (g2r1m1b29)

"...the video helps us to understand what the teacher has taught..." (g2r2m2b1) 


\section{ENRICHING KNOWLEDGE}

In this study, students' feedback has shown that the use of Edmodo application can enrich their knowledge. Several sub themes of this second theme, namely easy to access information and the inclusion of Elementary Thinking Skills elements (KBAT) have been obtained.

Using the Edmodo application, information is easily accessed by students in order to acquire material on learning via note links and Blind Spaces application that have been uploaded on the Edmodo page. This was proven by interviews conducted to the respondent 2 . He stated that the uploaded notes link provided the required information on teaching values, besides simple and easy notes to understand. Here are the quotes of the respondent 2 in an interview:

"...the difference is that the traditional way of learning does not allow us to find the required information, but by using Edmodo application it becomes easier to get the information..."

(G1R2M1B18)

Apart from the note link, through Blind Spaces as well, students can acquire knowledge about the learning delivered by the teacher. Blind Spaces is a new form and style of note reading using a technology application which includes videos, pictures, songs and notes material in a notes file. The interviews conducted in the second circle among several respondents indicated the advantages of obtaining information access using Blind Spaces. For example, respondents 3 expressed that through the use of Blind Spaces he can understand the content of learning more clearly than reading the book. Here is his interview:

"...so much different, we normally use books and self-learning, we write what ever the teachers told us to, but with Edmodo application we can obtain more knowledge and and can learn everything in the website with friends which is clearer than books". (G2R3M1B22)

An analysis of the document conducted on student reviews in Blind Spaces notes showed that students can understand the value of the teaching delivered. Blind Spaces provides a sense of understanding to student in learning. In the Blind Spaces note, issues related to the sacrifices of national security personnel, namely police members, are highlighted. The researcher asked students to comment while reading the notes they had seen. Respondent 7 for example has shown proper judgment through conscience regarding the services of national security personnel. Here is the comment of respondent 7:

"I feel sympathetic to the police who have sacrificed. At the same time, I am proud of having a brave Royal Police Forces who always ensure the peace of the nation." (AD/G2/BlindSpaces/M7)

The second sub theme was the application of the KBAT elements. Through the analysis of the study, the students have shown good feedback as they enriched the knowledge through the activities and the questions given from KBAT elements. From the first circle of the study, respondent 4 stated on the KBAT elements which have been included in activities such as 
INTERNATIONAL JOURNAL OF ACADEMIC RESEARCH IN PROGRESSIVE EDUCATION AND DEVELOPMENT

Vol. 7, No. 4, 2018, E-ISSN: 2226-6348 ๑ 2018 HRMARS

induction sets. He emphasized that the KBAT elements required him to think for answering the given questions. Here is his interview:

"...the advantage is that we can learn in a better way rather than getting the information from text books and we can also think with the KBAT questions in the video". (G1R4M1B23)

In this study, the researcher has provided KBAT questions to test and reinforce the students' understanding on the value of learning delivered. Analysis of document was conducted on activities and exercises of KBAT on Edmodo pages. Through the analysis of the documents in the activities carried out on the first circle, the students demonstrated the mastery of the KBAT elements in answering the question given. For example, in the KBAT exercise, average student achievement was $75 \%$ equivalent to $A-(A D / G 1 /$ KBATExercise). The answers given by the students also demonstrated the enrichment of knowledge through thoughtful arguments in line with the basics and principles of the KBAT questions formulated.

In addition, the comment of respondent 12 presented below has clearly showed his high-level thinking on the questions given. The KBAT questions asked about the role that a student can do to ensure that the country's name continues to be respected in the eyes of the world in meeting the challenges of the new millennium. The student pointed out that the role of a student is certainly to achieve excellence in knowledge, especially in science and technology. He also emphasized the role of students by avoiding any negative symptoms that could damage the country. Here is the quote of the student's comment:

"The effort that can be done to ensure that the name of the country continues to be respected in the eyes of the world is by avoiding negative elements as a student. For example, smoking and taking drugs. Taking drugs not only can undermine the reputation of a country, but also can cause death. In addition, I will study hard and strive to advance in science and technology so that I can serve the nation to be outstanding as other developed countries."

(AD/G1/LatihanKBAT/Murid12)

\section{Discussion and Conclusion}

This study presents the effectiveness of Edmodo application in the teaching and learning process of Moral Education subject at school. Students have given good feedbacks on using this application. This application is accessible to students as it is similar to other commonly accessed applications such as Facebook, Instagram and Twitter (Mohamad Amin, 2012). The easy accessibility provides space for students to carry out the learning process properly by using this application. Due to the familiar use of these applications, the students will deal with no difficulty while handling this application as well as manifesting the student's focus on learning. This was demonstrated in the interviews when the students stated that the application was very easy to use and their focus on learning was uninterrupted. Students also enjoyed using this application because the learning medium generated was interactive.

Student-centered learning and emphasis on group activity also give impact on students' feedback on the use of this application. In this study, the students were very excited to use the forums 
Vol. 7, No. 4, 2018, E-ISSN: 2226-6348 @ 2018 HRMARS

when they interacted online with the group members directly to discuss the issues raised. All students demonstrated an active role in the learning process. An authentic assessment emphasized in this study using the interactive medium also encouraged the students' interest. The new style of answering the questions has led to a new change in the method of answering questions. When finished answering the questions, the total score obtained by the students has been informed and tips provided by the researchers were given. This can be seen through interviews and reflection journals in the study when the majority of students liked this form of assessment.

The good effect that justified the main feedback in this study was when students have been able to answer KBAT questions. Through the analysis of first and second circle, the marks and quality of the answers given by the students were very rational. Thus, students were given learning information using interactive web links, as well as Blind Spaces notes that were very interesting and easy to understand throughout the learning process. Students were also presented with selfconceptual and student-centered learning concepts through group discussion and selfassessment of the issues raised, thereby stimulating students' thinking power.

From this study, researchers have been able to inspire a virtual learning method that has helped a teaching process, especially the subject of Moral Education. It is not easy to attract students to learning, but if there is an interesting method and innovation, of course, students' feedback can be improved. Researchers intend to continue this study by diversifying the use of information technology-based learning medium or better known as Learning Management System (LMS) such as Schoology and ClassDojo. The use of this LMS medium is very interesting and efficient especially in developing the pattern and form of teaching more in addressing the ever-increasing students in the 21 st century.

In addition, the researchers also intend to incorporate Social Media Network (SMN) to diversify effective instructional materials to assist the teaching process of students in the subject of Moral Education in future research. In this study, researchers only involved Form 4 students of science course, and therefore the researchers intend to apply this study to students of humanity course in future. The researchers also feel that this study should be carried out to students at the lower secondary level as early exposure should be done as well as to develop teaching methods to all ages, particularly at the secondary level.

\section{References}

Gabriela, G. \& Carmen, H. (2010). Microblogging multimedia-based teaching methods best practices with Cirip.eu. Procedia Social and Behavioral Sciences. 2(2010) :

2151-2155.

Faiezi, H. (2016). Kajian Tindakan Penggunaan Aplikasi Edmodo Dalam Pengajaran dan Pembelajaran (PdP) Pendidikan Moral. (Unpublished Master Thesis) Faculty of Education, National University of Malaysia.

Howell, Y.U \& Howell, S.N.(2003). What is your digital story?. NZ: Library Media Connection. 
INTERNATIONAL JOURNAL OF ACADEMIC RESEARCH IN PROGRESSIVE EDUCATION AND DEVELOPMENT

Vol. 7, No. 4, 2018, E-ISSN: 2226-6348 @ 2018 HRMARS

Balasubramaniam, K. (2014). A study on "Student preference towards the use of Edmodo as a learning platform to create responsible learning environment". Procedia Social and Behavioral Sciences 2. 144(2014): 416-422

Kemmis, S \& McTaggart, R. (1988). The action research planner. Victoria Australia: Deakin University Press.

Kreijns, U., Kirschner, T. \& Jochems, D.(2003). I dentifying the pitfalls for social interaction in computer supported collaborative learning environments. A review of the research Computers in Human Behaviour,19(3) : 335-353.

Kongchan, C. (2014). How a non-digital-native teacher makes use of Edmodo. The International Academic Forum - International Conference ICT For Language $5^{\text {th }}$

Edition 2013, hlm. 249-261.

Ministry of Education Malaysia (2001). Pembangunan pendidikan 2001-2010. Kuala Lumpur: AG Grafik Sdn. Bhd.

Monalisa \& Ardi, H. (2013). Using Edmodo educational social network on teaching english for high school students. Padang: Penerbitan University of Padang, Indonesia.

Embi, M. A. (2012). Aplikasi perangkaian sosial web 2.0 dalam pendidikan. Bangi: pusat pembangunan akademik universiti kebangsaan malaysia

Stahl, G. (2006). Group cognition: computer support for building collaborative knowledge. Cambridge: MIT Press.

Thongmak, M. (2013). Social Network system in classroom : antecedents of Edmodo (C) adoption. Journal of e-Learning and Higher Education.2013(2013): 1-15.

Balakrishan, V. (2012). Dilema kehidupan sebenar dalam pendidikan moral. Kuala Lumpur: Penerbit Universiti Malaya.

Yagci, T. (2015). Mobile social media in higher education \& implementation of "EDMODO" in reading classes. 6th International Visible Conference on Educational Studies and Applied Linguistics, pg. 1021-1022. 